Sigma Teknika, Vol.2, No.2 : 242-249

November 2019

E-ISSN 2599-0616

P ISSN 2614-5979

\title{
SISTEM KEAMANAN SEPEDA MOTOR BERBASIS GPS DAN ANDROID
}

\author{
Johan Manurung ${ }^{1}$, Missyamsu Algusri ${ }^{2)}$ \\ ${ }^{\mathbf{1 , 2}}$ Program Studi Teknik Elektro, Fakultas Teknik, Universitas Riau Kepuluan Batam \\ Email : johanzmanurung@yahoo.co.id
}

\begin{abstract}
Abstrak
Kasus pencurian dan pengambilan paksa kendaraan bermotor semakin sering terjadi di kalangan masyarakat seluruh Indonesia. Masyarakat yang menjadi korban tidak hanya kehilangan materi, tapi terkadang juga dapat kehilangan nyawa. Oleh karena hal tersebut diperlukan sistem keamanan tambahan yang lebih baik pada penggunanya maupun pada kendaraan itu sendiri serta mudah digunakan oleh pemilik kendaraan. Salah satu piranti yang dapat digunakan untuk membantu memenuhi keamanan tersebut adalah android. Penelitian ini bertujuan untuk menciptakan rancang bangun sistem keamanan sepeda motor yang memanfaatkan GPS dan android. Sistem ini dilengkapi fitur keamanan dan dapat menampilkan posisi kendaraan sepeda motor pada aplikasi google maps yang tersedia pada android. Penelitian ini dilakukan dalam dua tahapan pelaksanaan yakni perancangan (perangkat keras /hardware dan perangkat lunak/software) dan pengujian (pengujian tunggal fungsi komponen/perangkat/piranti, pengujian subsistem, dan pengujian sistem keseluruhan). Data penelitian ini berupa subsistem deteksi GPS, komunikasi GSM, dan aksi dua buah relay. Hasil penelitian ini menunjukkan bahwa sistem keamanan sepeda motor berbasis GPS dan Android telah sesuai dengan ketentuan fungsi sistem. Pengiriman data modul GSM dan arduino uno melalui web server terlaksana dengan baik dengan persentase keberhasilan sebesar $80 \%$. Radius toleransi ideal sensor GPS yang digunakan pada penelitian ini adalah 3,6 m berbeda dengan ketentuan pada datasheet, hal ini dapat terjadi disebabkan toleransi komponen serta kondisi lain yang menyebabkan sensor GPS tidak berada dalam kondisi ideal sesuai dengan datasheet.
\end{abstract}

Kata kunci - GPS, GSM, Android, sistem keamanan, Arduino Uno.

\begin{abstract}
The case of stealing and forced motor vehicle taking is increasingly common among the people throughout Indonesia. The affected communities not only lose material but sometimes also lose their lives. Because it requires additional security system better on the user or on the vehicle itself and easy to use by vehicle owners. One of the tools can be used to help meet such security is android. This research aims to create a design of motorcycle security system that utilizes GPS and Android. The system is equipped with security features dan can display the position of the motorcycle on google maps application available on android. This research is carried out in two stages of implementation, namely design (hardware and software) and testing (single component/device/device testing, sub system testing, and overall system testing). This research data in the form of GPS detection, GSM communication, and action of two relay. The results of this study indicate that the security system based on GPS and Android motorcycles has been in accordance with the provisions of system function. The delivery of GSM and Arduino Uno module data via web server is dine well with the percentage of success is $80 \%$. The ideal tolerance radius of the GPS sensor used in this study is 3,6 meter in contrast to the provisions in the datasheet. This can occur due to component tolerances and other conditions that cause GPS sensors are not in ideal conditions according to the datasheet.
\end{abstract}

Keyword-GPS, GSM, Android, Security System, Arduino Uno. 
Sigma Teknika, Vol.2, No.2 : 242-249

November 2019

E-ISSN 2599-0616

P ISSN 2614-5979

\section{PENDAHULUAN}

Dewasa ini, perkembangan teknologi sudah sangat jauh berkembang dari zaman ke zaman. Teknologi selalu mengisi setiap sudut kehidupan manusia, mulai dari hal yang sederhana sampai hal yang kompleks.

Sebagai gambaran, sekarang sudah berkembang teknologi IoT. IoT merupakan singkatan dari "Internet of Things" dimana setiap sistem memungkinkan untuk dikontrol dan dipantau dari jarak jauh. Data pada teknologi IoT terpusat pada sebuah server dan bersifat online.

Masuknya IoT ke sistem keamanan juga dilatar belakangi oleh maraknya kasus kriminal. Salah satu contohnya, sekarang banyak terdengar kasus pencurian sepeda motor. Salah satu usaha untuk mencegah kasus pencurian terjadi adalah dengan cara menambahkan sistem keamanan pada sepeda motor tersebut.

Penelitian ini sudah pernah dikerjakan oleh Mutaka Fadillah Hanofridho dengan judul penelitian "Sistem Keamanan Sepeda Motor Berbasis GPS". Pada sistem tersebut semua proses pengiriman data masih berbasis text. Pada kesempatan kali ini, penulis ingin mencoba membuat penelitian yang berjudul "Sistem Keamanan Sepeda Motor berbasis GPS dan Android", yang merupakan pengembangan dari sistem yang sudah ada. Pada penelitian ini, data akan dikirimkan pada sebuah server kemudian dari data ini nantinya akan dimanfaatkan sebagai notifikasi kepada pemilik dalam bentuk notifikasi berbasis teks maupun panggilan telepon. Sistem yang dibuat juga memanfaatkan aplikasi android, sehingga pemilik dapat mematikan sepeda motor jarak jauh serta dapat memantau posisi sepeda motornya.

\section{BAB II LANDASAN TEORI}

Dalam penelitian ini, penulis menjelaskan landasan teori tentang komponen-komponen yang digunakan dalam perancangan sistem keamanan sepeda motor berbasis GPS dan Android.

\subsubsection{Modul GPS Ublox Neo-6 Series}

Modul GPS Ublox Neo-6 Series merupakan sebuah modul yang dapat digunakan untuk mengetahui posisi atau lokasi yang diperoleh dari satelit navigasi. Lokasi yang didapat adalah lokasi longitude dan latitude hasil dari pengolahan data sinyal dari satelit.

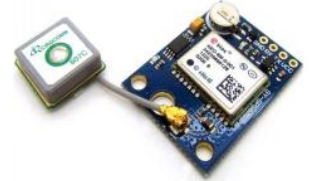

Gambar 2.1 Modul GPS Ublox Neo-6 Series[1]

\subsubsection{Modul SIM800}

Modul SIM800 merupakan modul GSM/GPRS yang memiliki fungsi selayaknya sebuah modem ataupun ponsel. SIM800 dapat digunakan untuk mengirim pesan, menelepon bahkan juga dapat digunakan untuk mengirim dan menerima data via sinyal GPRS.

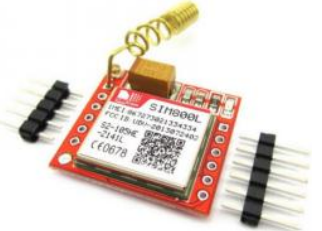

Gambar 2.2 Modul GSM/GPRS SIM800[2]

\subsubsection{Relay}

Relay merupakan sebuah komponen elektronika yang termasuk komponen elektromekanik. Relay terdiri dari dua bagian coil dan bagian saklar mekanik. Pada bagian coil biasanya dilengkapi dengan inti besi, sehingga saat diberi tegangan akan muncul medan magnet sehingga coil akan berfungsi sebagai electromagnet.

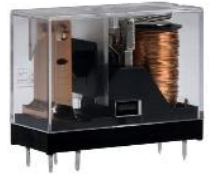

Gambar 2.3 Relay[3]

\subsubsection{Arduino}

Arduino merupakan sebuah platform yang bersifat open-source sehinga dapat digunakan dan dapat dikembangkan oleh siapa saja. Arduino terdiri dari 2 bagian utama, yaitu perangkat lunak dan perangkat keras. Perangkat 
Sigma Teknika, Vol.2, No.2 : 242-249

November 2019

E-ISSN 2599-0616

P ISSN 2614-5979

lunaknya berupa sebuah aplikasi yang disebut arduino IDE dan perangkat kerasnya berupa sebuah board minimum sistem. Pembuatan program pada arduino menggunakan bahasa $\mathrm{C}$ yang familiar bagi sebagian besar para pembuat program.

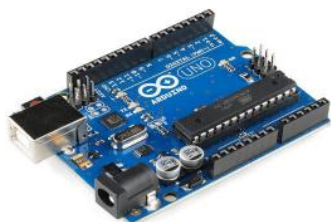

Gambar 2.4 Arduino Uno[4]

\subsubsection{Thunkable}

Thunkable merupakan sebuah aplikasi pemrograman yang bersifat online, yang dapat digunakan untuk membuat program android. Thunkable menyediakan dua layar utama yaitu layar Designer dan layar Block. Layar Designer digunakan sebagai tempat untuk mendesain tampilan aplikasi, kemudian layar Block merupakan tempat mendesain program.

\subsection{Hipotesis}

Sensor GPS dapat digunakan untuk mengetahui posisi dengan membaca koordinat lintang dan bujur bumi. Maka saat motor berpindah tempat, sistem dapat mengetahui posisi perpindahan sepeda motor. Saat perpindahan tanpa izin terjadi, sistem akan memberikan notifikasi berupa panggilan atau sms kepada pemilik sekaligus menyimpan data posisi secara online pada server.

\section{METODOLOGI PENELITIAN}

\subsection{Alat dan Bahan}

Perancangan sistem keamanan sepeda motor menggunakan sensor GPS dan modul GSM/GPRS berbasis arduino uno ini menggunakan beberapa alat dan bahan untuk dapat terlaksananya perancangan ini. Adapun alat dan bahan yang dipakai adalah sebagai berikut:

3.1.1 Alat

1. Solder

2. Gergaji besi

3. Bor tangan
4. Obeng

5. Tang kombinasi

6. Multimeter

\subsubsection{Bahan}

1.Timah

2. PCB

3. Modul GSM

4. Modul GPS

5. Arduino Uno

6. DC to DC Regulator

\subsection{Perancangan Sistem}

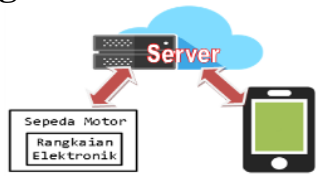

Gambar 3.1 Gambaran umum sistem Perancangan sistem keamanan ini melibatkan perancangan perangkat keras dan perancangan perangkat lunak.

\subsection{Perancangan Perangkat Keras}

Bagian utama dari perangkat keras adalah rangkaian elektronik. Rangkaian elektronik ini secara umum terdiri dari tiga bagian, yaitu:

1. Perangkat Masukan

Terdiri dari sensor GPS dan relay.

2. Proses

Bagian proses merupakan komponen utama yaitu kontroller. Kontroller yang digunakan adalah Arduino Uno.

3. Perangkat Keluaran Berupa modul komunikasi SIM800 dan relay.

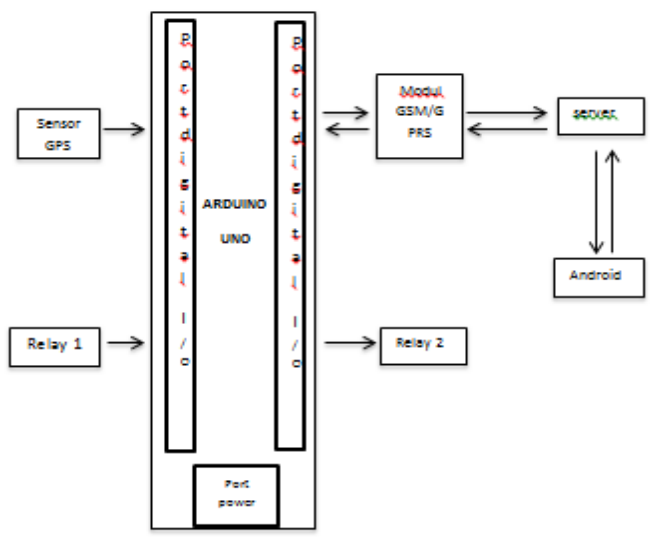


Gambar 3.2 diagram blok sistem keamanan sepeda motor

Dari diagram blok pada gambar 3.2, perangkat masukan terdiri dari dua komponen yaitu relay 1 dan sensor GPS. Relay 1 digunakan untuk membaca kondisi sepeda motor. Sedangkan sensor GPS berfungsi sebagai pembaca lokasi sepeda motor. Data yang dihasilkan oleh perangkat masukan akan diolah dan akan diteruskan ke perangkat keluaran. Perangkat keluaran terdiri dari modul komunikasi SIM800 dan relay. SIM800 berfungsi untuk mengirimkan data ke lokasi ke server yang nantinya akan diteruskan ke relay. Data perintah ini berupa perintah kontrol $O N$ dan $O F F$ sepeda motor

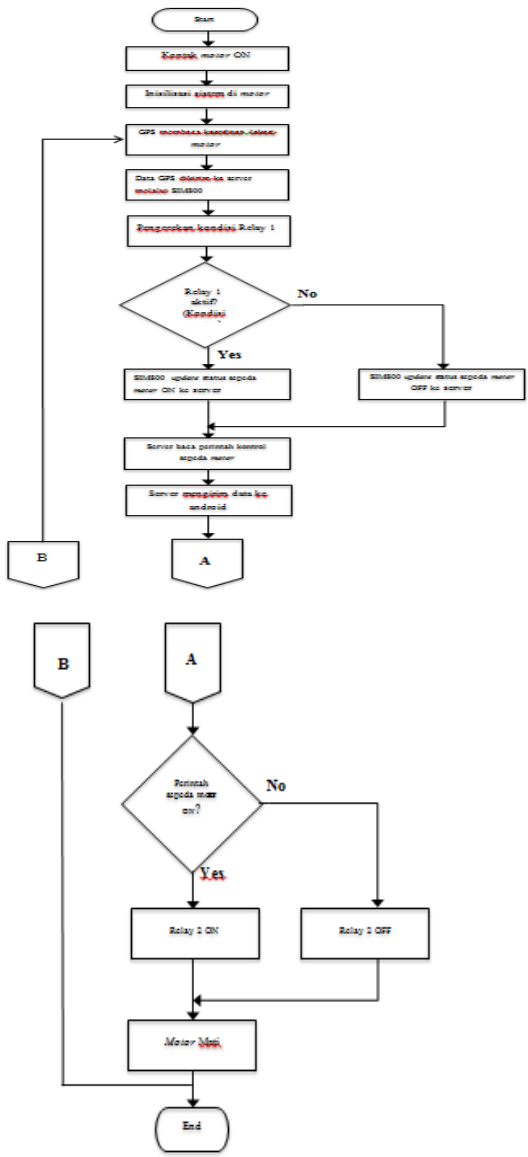

Gambar 3.3 Flowchart perangkat keras

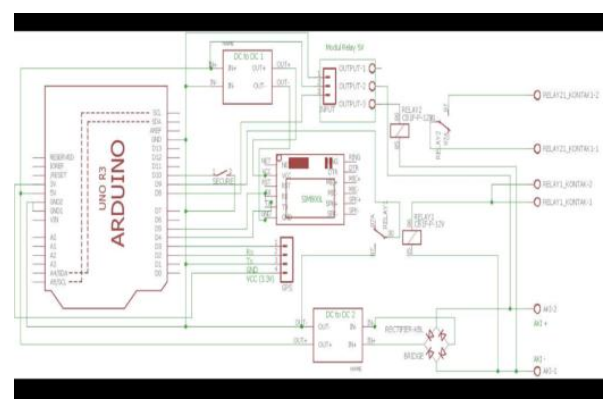

Gambar 3.4 Skematik rangkaian hardware system

\subsection{Perancangan perangkat lunak}

Perancangan perangkat lunak terbagi menjadi dua bagian. Bagian pertama adalah perangkat lunak untuk kontroller yang dibuat dengan arduino IDE dengan bahasa $\mathrm{C}$ sebagai bahasa pemrogramannya. Perangkat lunak yang kedua berupa aplikasi android yang dipasang pada smartphone pemilik sepeda motor untuk mengontrol $O N$ dan $O F F$ sepeda motor dan untuk memantau posisi motor secara realtime.

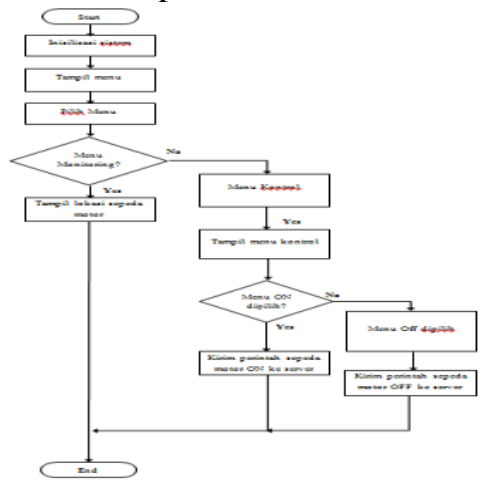

Gambar 3.5 Flowchart aplikasi android

\subsubsection{Perancangan software arduino IDE}

Perancangan ini merupakan perancangan

pemrograman pada arduino IDE agar mikrokontroller yang bertujuan menjalankan rangkaian elektronik sistem keamanan sepeda motor dapat berjalan sesuai ya 
Sigma Teknika, Vol.2, No.2 : 242-249

November 2019

E-ISSN 2599-0616

P ISSN 2614-5979

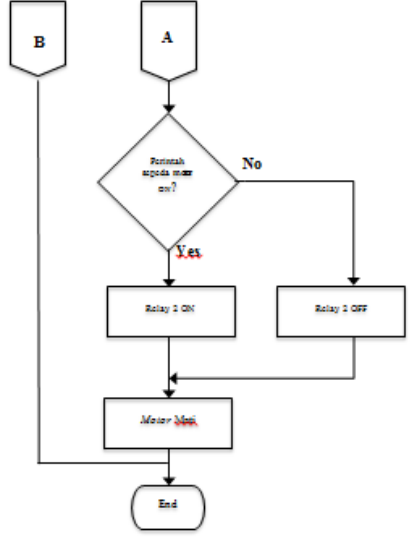

Gambar 3.3 Flowchart perangkat keras

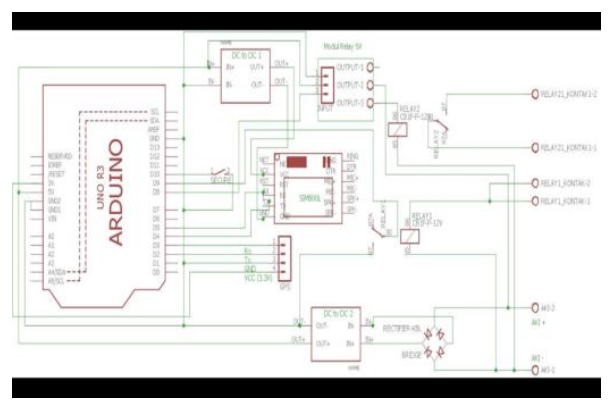

Gambar 3.4 Skematik rangkaian hardware system

\subsection{Perancangan perangkat lunak}

Perancangan perangkat lunak terbagi menjadi dua bagian. Bagian pertama adalah perangkat lunak untuk kontroller yang dibuat dengan arduino IDE dengan bahasa $\mathrm{C}$ sebagai bahasa pemrogramannya. Perangkat lunak yang kedua berupa aplikasi android yang dipasang pada smartphone pemilik sepeda motor untuk mengontrol $O N$ dan $O F F$ sepeda motor dan untuk memantau posisi motor secara realtime.

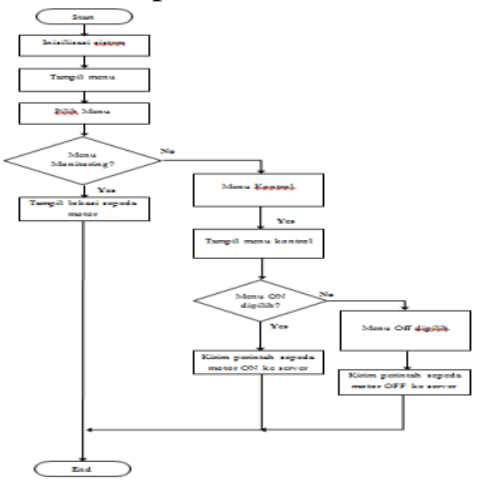

Gambar 3.5 Flowchart aplikasi android

\subsubsection{Perancangan software arduino IDE}

Perancangan ini merupakan perancangan

pemrograman pada arduino IDE agar

mikrokontroller yang bertujuan menjalankan

rangkaian elektronik sistem keamanan sepeda

motor dapat berjalan sesuai yang kita inginkan.

\subsubsection{Perancangan software aplikasi android}

Perancangan software ini merupakan perancangan dengan menggunakan aplikasi thunkable untuk membuat sebuah aplikasi tracking sepeda motor pada smartphone kita yang memungkinkan kita untuk memantau sepeda motor kita serta melakukan perintah lain seperti untuk memberi perintah kepada mikrokontroller untuk mematikan sepeda motor kita apabila terjadi pencurian.

\section{HASIL DAN PEMBAHASAN}

4.1 Hasil pengambilan data

Pengambilan data merupakan sebuah proses yang dilakukan untuk mengetahui parameterparameter yang terdapat pada sistem yang telah dirancang.

\subsubsection{Pengambilan data pada perangkat keras} 1. Data pengujian relay 1

Tabel 4.1 Data pin NO relay 1

\begin{tabular}{|c|c|}
\hline Kondisi Relay 1 & Tegangan $(\mathrm{V})$ \\
\hline On & 0 \\
\hline Off & 4.98 \\
\hline
\end{tabular}

2. Data pengujian relay 2

Tabel 4.2 Data pengujian relay 2

\begin{tabular}{|c|c|c|}
\hline No. & Tegangan(V) & Kondisi Relay 2 \\
\hline 1 & 0 & Off \\
\hline 2 & 5 & On \\
\hline
\end{tabular}

Berikut merupakan tabel pengukuran tegangan dari perangkat keras sistem pada saat alat sedang dijalankan atau dalam posisi running.

Tabel 4.3 Pengukuran tegangan saat running

\begin{tabular}{|c|c|}
\hline Komponen & Tegangan (Volt) \\
\hline Relay 1 & $12 \mathrm{~V}$ \\
\hline Driver relay 2 & $5 \mathrm{~V}$ \\
\hline Relay 2 & $12 \mathrm{~V}$ \\
\hline
\end{tabular}


Sigma Teknika, Vol.2, No.2 : 242-249

November 2019

E-ISSN 2599-0616

P ISSN 2614-5979

\begin{tabular}{|c|c|}
\hline GSM & $3,7 \mathrm{~V}$ \\
\hline GPS & $3,3 \mathrm{~V}$ \\
\hline
\end{tabular}

3. Data pengujian sensor GPS

Tabel 4.4 Data sensor GPS

\begin{tabular}{|c|c|c|c|c|c|}
\hline \multirow{2}{*}{$\begin{array}{c}\text { Pengujian } \\
\text { Ke- }\end{array}$} & \multicolumn{2}{|c|}{ Data Lokasi Sebenamya } & \multicolumn{2}{|c|}{$\begin{array}{l}\text { Data Lokasi Pembacaan Sensor } \\
\text { GPS }\end{array}$} & \multirow{2}{*}{$\begin{array}{l}\text { Penyimpan } \\
\text { gan Lokasi } \\
\text { (m) }\end{array}$} \\
\hline & Longitude & Latitude & Longitude & Latitude & \\
\hline 1 & \multirow[t]{10}{*}{104.0873900} & \multirow[t]{10}{*}{1.1188030} & 104.0873800 & 1.1188220 & 2.3 \\
\hline 2 & & & 104.0873800 & 1.1188170 & 1.8 \\
\hline 3 & & & 104.0873900 & 1.1188170 & 1.5 \\
\hline 4 & & & 104.0873800 & 1.1188170 & 1.8 \\
\hline 5 & & & 104.0873900 & 1.1188000 & 0.6 \\
\hline 6 & & & 104.0873800 & 1.1187890 & 1.9 \\
\hline 7 & & & 104.0874100 & 1.1187760 & 3.6 \\
\hline 8 & & & 104.0873800 & 1.1188220 & 2.3 \\
\hline 9 & & & 104.0873900 & 1.1188170 & 1.5 \\
\hline 10 & & & 104.0873900 & 1.1188340 & 3.5 \\
\hline
\end{tabular}

Pengujian dan pengambilan data dilakukan dengan cara berdiam di satu lokasi, kemudian melihat data koordinat lintang dan bujur, lokasi tersebut memanfaatkan fitur google maps.

4. Data pengujian modul GSM

Pengujian modul GSM ini dilakukan dengan beberapa cara, yakni:

a.Pengujian koneksi dengan arduino

Pengujian ini dilakukan dengan cara menghubungkan antar modul GSM dengan arduino dengan mengirimkan perintah berbentuk AT-Command ke modul GSM.

b.Pengujian koneksi dengan web server Pengujian ini dilakukan dengan cara mengakses web server melalui file yang telah tersedia di web server.

c. Pengujian pengiriman SMS

Pengujian ini dilakukan dengan cara memberikan perintah AT-Command kirim sms ke modul GSM. Contoh perintah jika ingin mengirimkan sms :

\section{$\mathrm{AT}+\mathrm{CMGS}="$ "+6281372498144"}

$>$ Coba kirim sms. $\rightarrow$

Berikut adalah respon dari modul GSM:

\section{+CMGS: 198}

\section{OK}

Tabel 4.5 Pengujian pengiriman SMS

\begin{tabular}{|c|l|l|l|l|}
\hline $\begin{array}{c}\text { Pengujia } \\
\text { n Ke- }\end{array}$ & $\begin{array}{c}\text { Teks yang } \\
\text { dikirim }\end{array}$ & $\begin{array}{c}\text { Teks yang } \\
\text { Diterima }\end{array}$ & $\begin{array}{c}\text { Waktu } \\
\text { Pengiriman } \\
\text { (detik) }\end{array}$ & Keterangan \\
\hline 1 & Coba SMS & Coba SMS & 20 & Berhasil \\
\hline 2 & Coba SMS & Coba SMS & 20 & Berhasil \\
\hline 3 & Coba SMS & Coba SMS & 20 & Berhasil \\
\hline 4 & Coba SMS & Coba SMS & 21 & Berhasil \\
\hline 5 & Coba SMS & Coba SMS & 18 & Berhasil \\
\hline 6 & Coba SMS & Coba SMS & 25 & Berhasil \\
\hline 7 & Coba SMS & Coba SMS & 25 & Berhasil \\
\hline 8 & Coba SMS & Coba SMS & 25 & Berhasil \\
\hline 9 & Coba SMS & Coba SMS & 20 & Berhasil \\
\hline 10 & Coba SMS & Coba SMS & 21 & Berhasil \\
\hline \multicolumn{7}{|l}{ Persentase Keberhasilan } & $100 \%$ \\
\hline
\end{tabular}

d.Pengujian panggilan telepon

Dilakukan untuk menguji fitur panggilan telepon yang ada pada modul GSM. Pengujian ini dilakukan dengan cara memberikan perintah $A T$ Command ke modul GSM untuk memanggil nomor telepon seluler yang telah ditentukan. Perintah AT-Command yang diberikan ke modul GSM adalah sebagai berikut : $\mathrm{ATD}<$ nomor $>$; $\langle\mathrm{CR}>\langle\mathrm{LF}\rangle$

Dimana :

$$
\begin{aligned}
& <\text { nomor }\rangle \rightarrow \text { nomor tujuan } \\
& \langle\mathrm{CR}\rangle \rightarrow \text { karakter " } \mid r \text { " (carriage return) }
\end{aligned}
$$$$
\langle\mathrm{LF}\rangle \rightarrow \text { karakter "In" (line feed) }
$$

Tabel 4.6 Pengujian pangilan telepon

\begin{tabular}{|c|l|l|l|}
\hline $\begin{array}{c}\text { Pengujian } \\
\text { Ke- }\end{array}$ & \multicolumn{1}{|c|}{ Nomor Tujuan } & \multicolumn{1}{|c|}{$\begin{array}{c}\text { Waktu } \\
\text { Sampai } \\
\text { (detik) }\end{array}$} & \multicolumn{1}{|c|}{ Keterangan } \\
\hline 1 & +6281372498144 & 6 & Berhasil \\
\hline 2 & +6281372498144 & 5 & Berhasil \\
\hline 3 & +6281372498144 & 7 & Berhasil \\
\hline 4 & +6281372498144 & 6 & Berhasil \\
\hline 5 & +6281372498144 & 6 & Berhasil \\
\hline 6 & +6281372498144 & 6 & Berhasil \\
\hline 7 & +6281372498144 & 5 & Berhasil \\
\hline 8 & +6281372498144 & 6 & Berhasil \\
\hline 9 & +6281372498144 & 10 & Berhasil \\
\hline 10 & +6281372498144 & 6 & Berhasil \\
\hline & Presentase Keberhasilan & $100 \%$ \\
\hline
\end{tabular}

\subsubsection{Pengambilan data pada perangkat} lunak

1. Pengujian web server dan Database

Pengujian ini dilakukan untuk menguji kinerja dari file php yang telah disediakan di server. File-file ini nantinya akan menjadi penyambung antara perangkat keras yaitu arduino ke database dan perangkat lunak android ke database.

a.Pengujian penyimpanan dan pengambilan data perangkat keras.

Pengujian ini dilakukan bertujuan untuk melihat kinerja program simpan dan ambil data yang ada pada server. 
Sigma Teknika, Vol.2, No.2 : 242-249

November 2019

E-ISSN 2599-0616

P ISSN 2614-5979

b. Pengujian penyimpan data perangkat lunak Pengujian ini dilakukan untuk melihat kinerja file simpanpengaturan.php dan file simpanperintahkontak.php yang ada di server.

c. Pengujian pengambilan data perangkat lunak

Adalah pengujian terhadap proses ambil data dari database kemudian ditampilkan di aplikasi.

2. Data pengujian aplikasi android

Pengujian perangkat lunak dilakukan untuk melihat kinerja aplikasi yang telah dibuat sudah sesuai dengan keinginan atau belum. Aplikasi ini akan di install pada smartphone pengguna. Aplikasi ini merupakan interface pengguna terhadap keseluruhan sistem. Dengan aplikasi ini, pengguna dapat melakukan pengaturan, monitoring serta kontrol pada sistem.

a. Menu tampilan lokasi sepeda motor

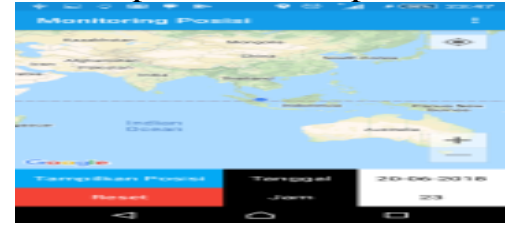

Gambar 4.1 Tampilan menu lokasi

Tampilan ini digunakan untuk menampilkan lokasi sesuai dengan koordinat lintang dan bujur yang tersimpan di database server hasil dari pembacaan sensor GPS yang ada pada perangkat keras.

b.Menu kontrol dan monitoring sepeda motor

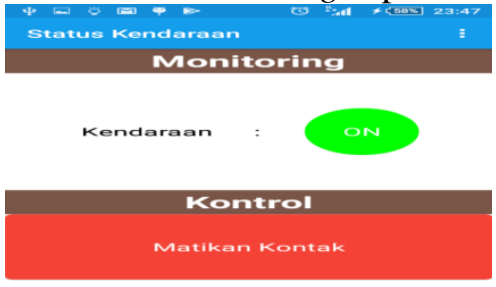

Gambar 4.2 Tampilan menu monitoring dan control sepeda motor

Tampilan menu kontrol dan monitoring sepeda motor berfungsi untuk menampilkan status relay 1 yang ada pada perangkat keras.

c. Menu pengaturan

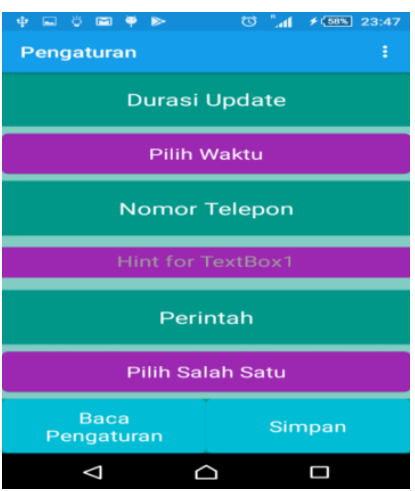

Gambar 4.3 Tampilan menu pengaturan

Меnu pengaturan merupakan sebuah menu yang ada pada aplikasi yang berfungsi untuk menyimpan dan membaca data pengaturan perangkat keras. Penyimpanan data merupakan proses simpan data dari aplikasi ke database.

\section{BAB V KESIMPULAN DAN SARAN A.Kesimpulan}

Setelah penulis berhasil merancang dan membuat alat serta melakukan pengujian, maka penulis menyimpulkan beberapa hal berikut ini:

1. Cara membangun sebuah sistem keamanan sepeda motor ialah dengan merancang alat yang terdiri dari perangkat keras dan perangkat lunak yang saling terhubung secara online dengan memanfaatkan server berbasis arduino uno, menggunakan modul SIM800 sebagai pengirim dan penerima data via sinyal GPRS, modul GPS untuk mengetahui posisi atau lokasi dari motor dan memanfaatkan relay sebagai pemutus kontak motor apabila ada pencurian.

2.Cara mencegah pencurian sepeda motor dengn menggunakan aplikasi android adalah dengan cara android dapat menampilakn data lokasi berdasarkan data yang tersimpan di server. Aplikasi dapat melakukan proses monitoring dan kontrol terhadap perangkat keras yang berfungsi untuk memonitoring relay 1 dan 2 serta memberi perintah untuk mematikan sepeda motor apabila terjadi pencurian.

DAFTAR PUSTAKA

[1]Datasheet NEO-6, u-blox.2011. \{6 Februari $2018\}$. 
Sigma Teknika, Vol.2, No.2 : 242-249

November 2019

E-ISSN 2599-0616

P ISSN 2614-5979

[2]Datasheet SIM800_Hardware Design_V1.08, Shanghai SIMCom Wireless Solution Ltd. 2015. \{5 Februari 2018\}.

[3]Pratama, D., Febriyanto, E.D., Hakim, D.A., et al. Sistem keamanan ganda pada sepeda motor untuk pencegahan pencurian dengan SMARTY (Smart Security). 2017

[4]"Arduino Uno Rev3", https://store.arduino.cc/usa/arduino-uno-rev3 \{diakses 3 Februari 2018\}.

[5]Thunkable,https://thunkable.com/\#/?show=ho wItWorks $\{5$ Februari 2018\}.

[6]Saputra, O.K. \& Herlinawati. Rancang bangun sistem keamanan Kendaraan Bermotor Berbasis GPS (Global Positioning System) dan koneksi Bluetooth.2015.

[7] Tri Mulyadi. "Desain dan pembuatan alat pengaman sepeda motor dengan sistem kontrol arduino". Skripsi tidak diterbitkan. Universitas Muhammadiyah Surakarta, Surakarta.2016

[8]Banzi, Massimo.Getting Started with Arduino $\left(2^{\text {nd }} e d\right)$. O’Reilly Media Inc.Sebastopol.2011

[9] Smith, G Alan. Introduction to Arduino. 30 September 2011 https://www.arduino.cc/en/Guide/Introduction \{3 Februari 2018\}. 